\title{
Hezkuntza eta Eskola: hezkuntza jardunbideen eta gizarte justuagoen bilakaeraren arteko zubi
}

\author{
Imanol Santamaria-Goicuria \\ Hezkuntzaren Teoria eta Historia \\ Hezkuntza, Filosofia eta Antropologia Fakultatea \\ Euskal Herriko Unibertsitatea UPV/EHU \\ imanol.santamaria@ehu.eus \\ Irantzu de Orbea Funes \\ Didaktika eta eskola antolakuntza \\ Hezkuntza eta Kirol Fakultatea \\ Euskal Herriko Unibertsitatea UPV/EHU \\ irantzu.deorbea@ehu.eus \\ Jon Martín-Etxebeste \\ (LAIDA Ikerketa Taldea) \\ Hizkuntzaren eta Literaturaren Didaktika \\ Bilboko Irakasleen Unibertsitate Eskola \\ Euskal Herriko Unibertsitatea UPV/EHU \\ jon.martine@ehu.eus
}

DOI: http://dx.doi.org/10.1387/tantak.19158

GAKO-HITZAK: Hezkuntza-jardunbideak, hezkuntza eta eskola, justizia soziala, bigarren hezkuntza, ikerketa narratiboa.

\section{SARRERA ETA GAIAREN AURKEZPENA}

Ez da erraza justizia soziala definitzea, eta are zailagoa da azaltzea zer den kontzeptu honek barne hartzen duen guztia. Nolabaiteko hurbilpena egitearren, Griffithsek (2003) proposatutako konparaziotik abia gaitezke. Horren arabera, justizia soziala «aditz» gisa uler liteke; jardunbide gisa, alegia. Ikuspegi horretatik, justizia soziala prozesu dinamiko gisa ikusi beharko litzateke: prozesu amaigabe gisa, hausnarketa eta hobekuntza eskatzen dituena, betiere, jomugan hartuta modu justu eta zuzenean banatzea pertsonek 
gizartean behar bezala garatzeko eta moldatzeko beharrezko dituzten oinarrizko ondasun eta zerbitzuak. Izan ere, birbanatze horrek bermatuko luke herritarrek bizi-kalitate handiagoa izan dezaten, hau da, arlo guztietan aukera gehiago izan ditzaten, eta pertsona hobeak ere izan daitezen.

Alabaina, zuzena izan arren, definizio hori ez da osoa, eta ez du justizia sozialaren kontzeptuaren dimentsioaniztasuna guztiz ondo islatzen, birbanatzearen ideiari baino ez baitio erreferentzia egiten (Rawls, 1971; Sen, 2010). Ez ditu aintzat hartzen justizia sozialak barne hartzen dituen funtsezko beste dimentsio batzuk, hala nola onarpenarena (Fraser, 1997; Cole, 2000; Irvine, 2003) edota ordezkaritzarena (Miller, 1999; Bell, 1997; Harnett, 2001; Lee eta Hipolito-Delgado, 2007). Fraseren arabera (2008), azken bi ideia horiek ezinbestekoak dira justizia sozialaren kontzeptuari hurbilpen dimentsioaniztuna eskainiko liokeen funts teorikoa garatzeko. Izan ere, Abiétar, Navas eta Marhuendari jarraiki (2015), justizia sozialaren kontzeptuak lotura zuzena du ordena sozialaren oinarrizko egiturekin; hau da, egitura ekonomiko, kultural eta politikoarekin.

Hori horrela, birbanatzearen kontzeptuak gidalerro batzuk eskainiko lituzke ondasun eta baliabide material zein kulturalak banatzeko. Era berean, finkatzen du zer faktore hartu beharko liratekeen kontuan banatze-prozesua bera egiteko.

Onarpenaren kontzeptuak, bestalde, zerikusia izango luke pertsona guzti-guztiei zor zaien aintzatespen sozial eta kulturalari, betiere gogoan izanik zein diren pertsonen identitateak eta nola sor daitezkeen bidezko harremanak haien artean.

Ordezkaritzaren ideiak, azkenik, pertsona oro legitimatuko lituzke esku hartzeko haien bizitzetan nolabaiteko eragina izan dezaketen erabakiak hartzeko prozesuetan. Alegia, printzipio honek xede izango luke bermatzea pertsonek parte-hartze aktibo eta bidezkoa izan dezaten bizi diren gizartean.

Hori horrela, hiru baldintza horiek betetzen ez diren egoeretan injustizia soziala ekar dezaketen jardunbideak garatzen direla. Bestela esanda, hiru printzipio horiek aintzat hartzeak baino ez ditu bermatzen justizia sozialeko jardunbideak; haatik, pertsonek parte-hartze osoko kondizioetan ager daitezen eta haien artean elkarreragiteko izan ditzaketen eragozpenek injustizia soziala indartzen dute (Abiétar et al., 2015).

Horrenbestez, zenbait autorek egindako ekarpenak aintzat hartuz (Fraser, 2008; Fraser eta Honneth, 2003; eta Griffith, 2003), oro har, honela defini daiteke justizia sozialaren kntzeptua: justizia soziala prozesu dinamiko bat da, hausnarketa eta hobekuntza eskatzen dituena aukera-berdintasuna bermatzeko prozesuan. Prozesu horrek ezinbestean bermatu beharko du oinarrizko ondasun eta zerbitzuak modu egokian banatuko direla ziurtatuko duten politika ekonomiko eta sozial berriak birformulatzea, identitate guzti-guztien aitorpena berrestea eta gizabanakoei ahalbidetzea bizitza sozialean ordezkaritza osoa izan dezaten. 
Pentsa liteke, beharbada, XXI. mendeko edozein gizartek hartu beharko lukeela aintzat justizia sozialaren ikuspegi hau; alegia, ezin litekeela bestela izan. Baina, egiari zor, egungo «jakintzaren gizartearen» testuinguruan -kapitalismoaren ondorioz, produkzio eta truke-sistema globalekiko menpekotasun gero eta handiagoa duen gizarte-eredu honetan-, arrakala soziala gero eta sakonagoa da.

Krisiak, globalizazioak eta produkzioaren eskakizunek areagotu egin dute zuzengabekeria. Hala, esate baterako, enplegu produktiboagoak eskatzen ditu sistema ekonomikoak. Enplegu horiek eskuratzeko, berriz, ikasketa-urte gehiago behar dira. Alabaina, ez dago bermatuta gizabanako guztiek aukera izan dezaten ikasketa horiek egiteko. Ondorioz, maila sozio-ekonomiko altuena duten pertsonek baino ez dute aukera enplegu horiek eskuratzeko, eta pertsona ugari geratzen dira garapenak dakartzan onurez gozatzen dituen taldetik kanpo.

Egoera honetan gero eta beharrezkoago dirudi desberdintasun horien kontra borrokatzea. Zalantzarik gabe, hezkuntza, oro har, eta, bereziki, eskola borroka-tresna indartsuak izan daitezke errealitate sozial horien kontra. Izan ere, nahiz eta hezkuntzak, berak bakarrik, eraldaketa soziala lortzeko gaitasunik ez izan, hura gabe ere ezingo litzateke halakorik egin (UNESCO, 2015). Baina, jakina, hezkuntza-eredu guztiek ere ez dute eraldatze hori bermatzen.

Horretarako, hezkuntzak berariaz egin beharko luke justizia soziala oinarri eta helburu dituen eraldaketa sozialaren aldeko motor izateko hautua (Murillo, Román eta Hernández-Castilla, 2011). Horrek eskatzen du atzean uztea gizartean egun indarrean den hezkuntza-eredua; alegia, lehiakortasunean eta produktibitatean oinarrituta, «giza kapitala» trebatzera bideratuta dagoen eredua, eta oso bestelako baliotan hezitako herritarrak sortzea bilatzen duen eredu baten alde egitea: heritar libreak, autonomoak, gogoetatsuak, demokratikoak, toleranteak, erabakitzaileak, trebeak eta injustizien aurrean sentikorrak, hau da, injustiziok salatzeko eta gizarte justuago baten alde lan egiteko prest daudenak (Murillo et al., 2011).

Alabaina, oso gogoan izatekoa da eskolak helburu horretan duen zeregina. Izan ere, lehen esan denez, eskola desberdintasunaren eta bazterketaren kontra borrokatzeko eragile indartsuenetakoa bada ere, ikasle asko baztertzen eta diskriminatzen ditu eskolak berak haien gaitasuna, adina, arraza, klase soziala, generoa edota sexu-orientazioa direla eta. Era berean, titulu eta egiaztagiri ofizialak emateko duen eskuduntza dela medio, eskola meritokrazian oinarrituriko gizarteak eragiten dituen desberdintasunak justifikatzen dituen bitarteko ere bada eskola bera. Horrela bada, ideia horretan du sorburu, hain zuzen ere, ikerlan hau gidatu duen galderak: Eskolak, instituzio gisa, erreproduzitu eta sakontzen ote ditu injustizia sozialeko egoerak? 


\section{AURREKARIAK}

Globalizazioa, migrazio-mugimenduak eta teknologia berriak ari dira zedarritzen gaur egungo gizartean bizi den etengabeko aldaketa. Etenik gabeko berrikuntza horrek eragina du eskolaren instituzioan. Izan ere, eredu honek zalantzan jartzen du jakintza eskurtzeko eta transmititzeko kultura tradizionala; era berean, areagotu eta aldatu egin ditu eskolari ezartzen zaizkion eskakizunak; horrez gain, zabaldu egin dira landu beharreko alderdiak: alfabetatze digitala (Mora, 2017), adimen emozionala (Bisquerra, 2016) ... Irakasleen jardunari ere eragiten dio horrek guztiak, aurreikuspen berriak baititu gizarteak haien rolaz eta haiengandik espero denaren inguruan.

Hortaz, gaur egun askotariko erronka ugariri egin behar zaie aurre, modu nabarmenean eragiten baitute, zuzenean nahiz zeharka, gizartearen garapen ekonomiko, sozial eta kulturalean. Garapen ekonomiko eta sozialak aberastasunaren zein aukeren banaketa bidezkoagoa ekarri beharrean, ekitate eza eta injustizia soziala areagotzen ditu egungo gizartean. Garapen horrek, aberastasunaren eta aukeren banaketa egokian oinarriturik, kalitatezko hezkuntza izan behar du bidelagun, gure mundu globalizatuaren parte izateko eta bertan parte hartzeko behar ditugun jakintzak, trebetasunak eta gaitasunak lortu eta garatu ahal izatea bermatuko duena. Freirek esan bezala: «Hezkuntzak ez du mundua aldatzen, mundua aldatuko duten pertsonak aldatzen ditu».

Horrenbestez, arreta berezia eskaini behar zaio eskolari, gizartea irudikatzeko funtsezko bitarteko gisa. Eskolako jardunbideek eta horiek ikasleengan dituzten ondorioek gizarte hobea ala okerragoa sortzen lagunduko dute, eta, beraz, mundu hobea ala okerragoa. Alegia, hezkuntza-politiken bitartez eragitea lortu behar da, oro har, hezkuntzak duen garrantzian, eta, zehazkiago, eskolan gertatzen den horretan zein hura osatzen duen giza kapitalean. Horiek izango dira gizarte justuagoak eraikitzeko funtsezko aldagaiak.

\section{IKERLANAREN GARRANTZIA ETA JUSTIFIKAZIOA}

Justizia soziala aukera berdintasunaren eremukoa da, identitate guzti-guztiak aitortuz eta ordezkatuz lortzen dena. Alabaina, Connellen arabera (1997), maila ekonomikoak zein hezkuntza-mailak erraztu egiten dute bereizketa hori. Gizarte-egoera ahuleko taldeak hasi ziren harreman horri buruzko galderak egiten, baina, zalantzarik gabe, jendarte osoarentzat dira garrantzitsuak.

Kontuan izan behar da ondasun publiko garrantzitsuenetakoa dela hezkuntza. Edozein gizarte modernoren motorrik indartsuenetakoa da, eta haren ordezkari instituzionalak, ikastetxeak, unibertsitateak eta abar oso garrantzitsuak dira bai gizarteetan, bai gizarteentzat, sistema produktiboetan dituzten eraginengatik, gehienbat. Hala, erabilera ekonomikoa hartzen dute.

Baina, era berean, aintzat hartu behar da lortutako erabilera ekonomiko horrek desberdintasunak sortzen dituela onuren banaketan: mailaz 
goratzeko eskubidea, hau da, titulu akademiko bat eskuratzeko ahalmena izatea, klase sozialaren araberakoa baita. Bordieu eta Passeronen (2014) teoría berproduzitzailearen arabera, modu honetan hezkuntzak ez du ziurtatzen norbanakoari jatorriz egokitu zaion klase soziala gainditzea; aitzitik, klase sozial berberean jarraitzera kondenatzen du norbanakoa.

Connellek (1997) esan bezala, baldin eta gaur egun hezkuntza-sistema, oro har, eta eskola, bereziki, erabiltzen dituen moduak hein handi batean baldintzatuko badu etorkizuneko gizartea bidezkoa izango den ala ez, eskolak bere jarduna eraldatu behar du, guztiei erantzun egokia eman ahal izateko, edozein direla ere haien desberdintasunak, baliabideak zein mugak. Modu horretan borrokatu ahal izango da eskola, desio kolektiboari jarraiki, gizarte justuagoak garatzeko bidean.

Justizia sozial handiagoaren aldeko borroka-prozesu horretan, eskolaren eragilerik esanguratsuenetakoa irakaslearen irudia da: bera da politiken eta jardunbideen arteko bitartekaria, desberdintasunen kontra mobilizatzeko eta bestelakotasunekiko errespetuaren alde egiteko bitartekoa. Hori dela eta, azpimarratzekoa da haien tentsioak nahiz jarduera profesionaleko dilemak aztertzeak duen garrantzia, eta, halaber, horrek guztiak nola eragiten dion identitateen eskolatzeari eta haien irakasle-identitatearen osaketari (Achili, 1996).

Ikus daiteke, beraz, zer garrantzi duten eskolak eta hezitzailearen eginkizunak bazterkeria gainditzeko funtsezko bitarteko gisa, kalitatea eta zuzentasuna oinarri harturik helduz, ikasleen aniztasunari, gizarte justuago bat eraikitzeko bidean. Kontuan izan behar da, alabaina, bi eragileok, haiek bakarrik, ezin dituztela konpentsatu desberdintasun sozialak eta ezin dituztela ezabatu gizarteetan dauden askotariko bazterkeria moduak. Horregatik, beharrezkoa da, aldi berean, hezkuntza-eremuan nahiz handik kanpo desberdintasuna eta bazterkeria sortzen dituzten faktoreei helduko dieten politika ekonomiko eta kulturalak egitea (Blanco, 2006).

Neurri horiek bi printzipio utziezinetan oinarritzen dira. Bata da aniztasunari erantzutea, zeinaren oinarria baita gobernuek eta haien hezkuntzasistemek guztioi hezkuntzarako eskubidea bermatzeko betebeharra (Dieterlen, 2001; Gordon, 2001). Bestea da gizarteratze-printzipioa, zeinak xedatzen baitu pertsona guztiek aukera-berdintasunean parte hartzeko eskubidea izatea, curriculum bera garatuta eta eskola-gune arruntean (Ainscow 2001; UNESCO, 2004).

\subsection{Irakasleen eginkizuna justizia sozialaren arloan}

«Ez da aldaketa sozial sakonik egongo, ezta demokrazia indartuko ere - eginkizun sozio-kulturalean jendearen benetako parte-hartze gisa-, non eta abiarazten ez den hezitzailearen ikuspuntu profesionaletik eta jarreren aldetik gaitasuna duen hezkuntza.» (FREIRE, 2002: 91) 
Arestian aipatu den moduan, hezkuntza eta eskola funtsezko bitarteko dira gizarte justu eta zuzenagoak eraikiko dituzten herritarrak hezteko. Hezkuntza horren oinarria da ikaskuntza bidezkoago eta integralagoen transmisioa, ikasleen beharretara egokitua izango dena; hau da, ikasleak abiapuntu eta helburu dituen ikaskuntza. Hezkuntza horrek behar-beharrezkoa du justizia sozialean oinarriturik eta justizia soziala lortzeko lan egingo duen eskola bat (Krichesky et al., 2011). Era berean, eskola horrek dagokion balioa eman behar dio aniztasunari, ikasleek zein irakasleek beren jakintzak eraikitzeko oinarrizko lehengai gisa (Martín eta Mauri, 2007). Hala, justizia, demokrazia eta zuzentasuna izango dira eskolaren zutabe nagusiak.

Eskola-eredu horrek, beraz, funtsean eskatzen du modu sakonean berraztertzea irakasleen eginkizuna, eta, ondorioz, haien jardunbideak. Norabide horretan, funtsezkoa da irakasleek ikusmolde horren postulatuekiko konpromisoa hartzea, modu esplizituan eta aktiboan, hala bermatuko baitira ikasgela, eskola eta jendarte sozialki justuagoak ekarriko dituzten ikaskuntza-prozesuak.

\subsubsection{Irakaslearen identitatea eta jardunbideetan duen eragina}

Identitatea osatzea nork bere burua berregiteko prozesua da. Prozesu hori gertatzen da organismo bat bere burua ezagutzeko gai denean eta gai denean, halaber, bere egiteko zenbait bereizgarri, portaera eta ekintzen ondorio (Monereo eta Pozo, 2011). Prozesu hori ez da sekula amaitzen eta askotariko egoerei desberdin erantzutea ahalbidetzen du. Gizabanakoek hiru faktorerekin duten etengabeko elkarrekintzaren ondorioz gertatzen da garapena. Alde batetik, haien «bereizgarri» biologiko, biografiko eta sozialaak leudeke - hor sartzen dira bizipenak, sinesmena, balioak...-. Bestetik, gainerako norbanakoekin duten harremana legoke. Azkenik, bizi eta osatzen duten testuinguruarekin duten elkarrekintzak eragingo luke (Sancho, Correa, Giró eta Fraga, 2014). Imbernonek (2008) adierazten duenez, horren guztiaren azken emaitza ikasleengan zuzenean edo zeharka eragiten duen jardunbide profesional bat da, irakaslearen identitatearen eraikuntzak, haren sozializazioak eta transmisioak erabateko garrantzia baitute hezkuntza-prozesuetan.

\subsubsection{Irakasleen prestakuntza}

Gizarte justuagoak garatu ahal izateko funtsezko faktoreetako bat kalitatezko hezkuntza edukitzea da. Horretarako, ezinbestekoa da hezkuntza aldatzea, eta horrek irakasleei prestakuntza on eta koherentea ematea eskatzen du; justizia soziala oinarri eta helburu duen prestakuntza, alegia.

Irakasleen prestakuntza jakintzak, metodoak eta balioak uztartzen dituen prozesu gisa irudikiatu behar da. Horrek esan nahi du prestakuntzajarduerak irakasleen jardunbiderako, eduki teoriko eta metodologiko ego- 
kiak ez ezik, barne hartu behar dituela, halaber, irakasleek hezkuntzaren beraren xedearekiko dituzten espektatibak ere, beti ere hezkuntza-politikak, eskolaren beraren zeregina eta ikasle bakoitzaren errealitatea eta berezitasunak kontuan harturik (Enterline, Cochran-Smith, Ludlow eta Mitescu, 2008).

Amaitzeko, eta aipatutako hura gogoan izanik (Krichesky et al., 2011), honela defini daiteke justizia soziala helburu duen irakasleen prestakuntza: justizia sozialaren helburuekin konprometitutako profesionalei zuzendutako garapen-prozesu bat, askotariko edukiak (metodologikoak, emozionalak, jarrerazkoak eta politikoak) garatuko dituen ikuspegi pedagogiko baten bitartez, elkarlana sustatuko den giroetan garatuko dena, jardunbidearekiko jarrera gogoetatsuak gidatutako ikuspuntu kritiko batetik egina, eta edozein ikaslek tokia izango duen hezkuntza-errealitateak sortzeko helburua izango duena.

Irakasleek ez dute «izate» edo «jardunbide» estatikoa; poliki-poliki egiten dute haien bidea, urratsez urrats garatzen dute haien izaera, eta ibilera horretan egiten dute ikasbidea. Hori dela eta, etengabeko prestakuntza funtsezko faktorea da profesionalizazio-ibilbide zabala ikusmiran (hasierako prestakuntza, irakaskuntzarako hautaketa eta sarbidea, irakaskuntzako lehenengo urteak, lanaren ebaluazio formatiboa...). Horrenbestez, beharrezkoa da prestakuntzarako aukerak sortzea eta erabiltzea, justizia helburu duen irakaskuntzarako gaitasun eta bitarteko didaktiko egokiak sortzeko baliagarriak izango direnak. Izan ere, bestela sarritan gertatu izan denez, eskolatze-prozesuek eta garapen curricularreko prozesuek gehiago balio izan dute desberdintasunak eta etiketatzeak justifikatzeko eta betikotzeko edota kontzientziak isilarazteko, zuzentasunaren eta kalitatearen arteko bidezko oreka ziurtatzeko baino (Karsz, 2004).

\section{HELBURUAK}

Ikerketa honen helburu orokorra ikastetxe bateko justizia sozialaren errepresantazioa zein den ezagutzea eskola errealitate horren baitan dauden praktika hezitzaileen analisiaren bidez. Honetarako ikastetxeko irakasleriaren lankidetzaren bidez jasotako esperientzia pedagogikoen kontakizunetatik justizia sozialaren bidean oztopo egiten duten elementuen identifikazio eta horien aurkezpena.

Helburu espezifikoak, berriz, bi hauek dira:

- Irakas lanbidearen aukeraketaren zergatiak eta horrek irakasleen lanaren garapenean duen eragina ezagutzea.

- Lanbidean zehar irakasleei sortu zaizkien dilemak eta tentsioak identifikatzea eta esplizitatzea. 


\section{METODOLOGIA}

Ikerlan honetan metodologia narratiboa erabili da. Ikuspuntu kontzeptualetik, eta Connelly eta Clandininen arabera (1990: 6), «ikerketa narratiboa da gizakiok mundua esperimentatzen dugun moduen azterketa», haren oinarria baita, zalantzarik gabe, ongien ezagutzen duguna; alegia, geure bizitza eta gertatzen zaiguna. Ikerketa narratiboaren ardatza giza esperientziaren azterketa da. Testu narratiboek balio handia dute ikaskuntza-bitarteko gisa, hein handi batean, bizipenetan oinarritzen baitira.

Narrazio-diseinuetan pertsona zehatzen bizi-historiei eta bizipenei buruzko datuak biltzen ditu ikertzaileak, eta ondoren horiek guztiak deskribatu eta aztertzen ditu. Datu horiek lortzeko, hainbat iturri erabiltzen dira: autobiografiak, biografiak, elkarrizketak, dokumentuak, tresna zein material pertsonalak eta testigantzak. Ikerketa narratiboa ikasteko aukerak sortzen dituen informazioa biltzeko prozesu bat da, pertsonek euren bizitzei buruz edota besteen bizitzei buruz kontatzen dituzten kontakizunen bitartez eraikitzen dena. Prozesu horretan, ezinbestekoa da aldez aurretik hausnarketa-lana egitea, adierazgarria ez den informazioa diskriminatzeko; hartara, ondoren, informazio esanguratsua bakarrik kontatuko da. Horren helburua hauxe da: irakurlearengan oihartzunak sorraraztea, eta, hala, gertatutakoari buruz hausnartzera gonbidatzen duen barne-elkarrizketa bilatzea.

Prozesu horrek guztiak ikaskuntza-komunitate bat sortzen laguntzen $\mathrm{du}$, zeinean parte diren pertsonek modu aktiboan egiten baitute lan eta, aldi berean, horri guztiari buruz hausnartzen baitute, beren laneko jardunbidea hobetzea edota aldatzea jomugan hartuta. Horretarako, subjektuartekotasunaren bitartez eskuratutako ikaskuntza izango dute oinarri, alegia, subjektuek beren esperientziei buruzko elkarrizketatik lortuko duten ikaskuntza (Wells, 2001) - esperientzia hori, bestalde, bizipenak bizi ondoren bildutako ondorioen emaitza da-.

\subsection{Ikerlanaren testuingurua eta kolaboratzaileak}

Ikerlana Euskal Autonomia Erkidegoko Bigarren Hezkuntzako eta Lanbide Heziketako itunpeko ikastetxe erlijioso batean egindakoa da. Hiri handi bateko ikastetxe handi bat da, hiru hizkuntza-eredu dituena: A, B eta D. Ikasleen maila sozioekonomikoari dagokienez erdi-mailakoa da.

Ikastetxe horretako hezkuntza-eredua integrazio-ereduan oinarritzen da nagusiki; hau da, ikasle guztiak daude ikastetxe berean eskolatuak, baina, batzuetan, hezkuntza-premia bereziko ikasleak laguntza-geletara edo gela iraunkor deritzen geletara ateratzen dira.

Kolaboratzaileei dagokienez, komenientzia-lagin bat (Polkinghorne, 2005) erabili da. Partaideak, ikastetxeko hiru irakasle izan dira, 45-50 urte bitartekoak hirurak: emakumezko bat (H2_E) eta bi gizonezko (H1_G; 
H3_G). Hiru irakasle hauek hautatu dira lankide aintzat hartuz hezkuntzarekiko agertu izan duten jarrera eta pentsamendu kritikoa.

Azterlan honetan haien esperientzia pedagogikoa aztertu da, eta kontatu dutena interpretatu da. Ondoren, ikertzaileek hezitzaile gisa duten esperientzia eta ikusmoldearekin alderatu da informazioa, irakasleen identitatea sortzeko eta eratzeko prozesua ezagutu eta ulertu nahian.

\subsection{Datuak biltzeko erabilitako bitartekoak}

Lan honetan, kontakizun autobiografikoez gain, informazioa biltzeko beste metodo kualitatibo batzuk ere erabili dira, hala nola behaketa, lanegunkaria, elkarrizketak, elkarrizketa horien audio-grabazioak eta dokumentuen analisia. Horien bitartez, sakon aztertu ahal izan dira irakaskuntza-jardunbideen esperientziak zein konplexutasunak eta haiei loturiko fenomenoak (adibidez, programa bat, politika bat, hezkuntza-erakunde bat, ikasgela bat...). Horiek guztiak interpretatzeko garaian erreferentzia gisa hartu dira batzuk zein besteak aplikatzen diren testuinguruaren ezaugarriak.

Edonola ere, bi izan dira datuen iturriak. Lehenik eta behin, kolaboratzaileekin egindako narrazio-txostenak erabili dira, haien bizi-historian zehar - jardunbide profesionalaren testuinguruan - izandako bizitza pertsonal zein profesionala kontatzen duten kontakizun autobiografikoetatik abiatuta sortutakoak (Mallimaci, 2010). Bigarrenik, egituratu gabeko elkarrizketa sakonak erabili dira. Izan ere, elkarrizketen bitartez, esanahiak aztertu daitezke, eta ikertzaileak eta parte-hartzaileek elkarren arteko kontakizun bat adostu dezakete.

Egituratu gabeko elkarrizketa sakon horiei esker - kontakizun autobiografikoak irakurri ondoren, ateratako ondorioak kontrastatzeko asmoz egiten direnak-, testu adostu bat sortzen da. Testu horretan, erantzunak adostu egiten dira, eta ikertzaileen egitekoa da, Arribas Cuberok (2008) adierazi bezala, jakintza eraikitzea, ez aldiz aurkitzea.

\subsection{Lortutako informazioaren trataera}

Ikerlan honen gaiari loturiko kategoria sortuberri ugari identifikatu ahal izan dira, elkarlanean (Saldaña, 2013). Hala, ondoren, elkarren arteko kontakizun bat eraiki ahal izan da (Holstein eta Gubrium, 2008), zeinaren xedea baita erlazionatzea irakaslearen identitatearen eratze-prozesua, gaur egungo gizartean gertatzen ari den aldaketa sozial zein hezkuntza-aldaketaren eta erlazio pedagogikoen ondorioz sortutako tentsioak eta dilemak, eta gizarte inklusiboagoen, eta, beraz, justuagoen eraikuntza. 


\subsubsection{Lortutako datuen kategorizazioa}

Hiru dimentsiotan kategorizatu dira lortutako datuak: a) irakasle izateko arrazoiak (zerk bultzatu zituen kolaboratzaileek irakaskuntza profesio gisa aukeratzera); b) irakaskuntza-jardunbideetan izandako dilemak eta gatazkak (kolaboratzaileen jardunbide profesionala baldintzatu duten bizipen positiboak eta negatiboak); eta c) (In)Justizia sozialari lotutako gaiak (gizarte justu bat garatzen laguntzen ez duten egoerak - gizarte justu bat, alegia, oinarrizko ondasun eta zerbitzuak modu egokian banatzen dituena, identitate guzti-guztien aitorpena berretsi eta bizitza sozialean haien ordezkaritza osoa ahalbidetzen duena-). Horiek dira aztertutako funtsezko dimentsioak. Horiekin osatu dute kolaboratzaileek beren identitate narratiboa, eta horiek hartu dira abiapuntu gisa, arestian aipatu bezala, elkarren arteko kontakizun adostu bat osatzeko unean. Horrenbestez, horiek izango dira, hain zuen, ikerlanaren emaitzak.

\section{EMAITZAK: KATEGORIEN AURKEZPENA}

Gai sortuberri ugari agertu dira azterlan honetan. Horiek guztiak hiru kategoria nagusitan bildu, eta modu narratiboan aurkeztu dira, metaforak erabiliz, zeinak, Lakoff eta Johnsonen arabera (1980), esperientziak beste modu batean ulertzeko bidea eskain baitezakete, eta jarduerei, eta jakiten den horri edota uste den orori, esanahi berria ematen laguntzen baitute. Era berean, kolaboratzaileen ahotsa ere erabili da, ahots horiek zentzua eta edukia baitakarkiote lanari (Rivas eta Herrera, 2009).

Emaitzak bi ataletan eman dira. Lehenbizi, kategoria bakoitzaren aurkezpena egin da, betiere, kolaboratzaileek esandakoetan eta elkarlanean egindako kategorizazio-prozesuan oinarrituta. Ondoren, berriz, kategoria bakoitzari dagozkion emaitzei buruzko eztabaida egin da; horretarako, metaforak erabili dira, irakurlearengan oihartzunak sorraraztearren eta gertatutakoari buruz hausnartzera gonbidatzen duen barne-elkarrizketa piztearren.

Prozesu horrek, bestalde, aldez aurretik hausnarketa-lana eskatu du, adierazgarria ez den informazioa diskriminatzeko, eta, hartara, ondoren, informazio esanguratsua bakarrik kontatzeko.

\section{Zergatik aukeratu zuten irakasle izatea}

«Uste dut gutxi gorabehera izango zela OHOko ikasketak amaitu nituen urtea, 1980. edo 1981 urtean. Urte hartan ezagutu nuen, gerora, nire egungo lanean «ispilu» izango nuen pertsona.» (H1_G)

Irakasle izatea hautatzeko arrazoien artetik, garrantzi nabarmena ematen diete eskola-garaian emozionalki modu positiboan eragin zieten eta ge- 
rora lanbidea hautatzean baldintzatu zituzten pertsona erreferente eta esanguratsu jakin batzuei.

«Gaur egun oraindik ere harremana dudan irakasle bat izan genuen ikastolan, 5 urtez izan genuen tutore. Gauza asko bizi izan genituen harekin, eta harremana oso ona izan zen. Gurekin utzi zion erretzeari, gurekin zegoela egin zuen soldadutza eta gutunak idazten genizkion elkarri; asko arduratu zen gure arteko harremanez. Hitz batez, irudipena izan nuen inporta geniola.» (H2_E)

Harremanen alderdi emozionalak duen garrantzia azpimarratzen dute, eta horrek duen eragina pertsonen identitatean eta, beraz, haien ikaskuntzaprozesuan. Prozesu horretan haientzat oinarrizkoak diren faktoreak aipatzen dituzte, hala nola apaltasuna; autokritikarako gaitasuna; eta harreman horizontalak - ez bertikalak - , kontuan hartuz mugek duten garrantzia. Horiek dira, haien ustez, irakaskuntza-ikaskuntza prozesuan ikasleek garapen egokia izateko funtsezko faktoreak.

«Hezkuntza, gizartearentzako eta pertsonentzako zerbitzu gisa. Halaxe ikasi nuen familian; inguruko pertsonak zoriontsu egiten jakin behar zen, bai ekintzen bitartez, bai isiltasunaren edota maitasunaren bitartez. Kurtsi samarra dirudi, baina horrek definituko luke gure gurasoek emandako eredua.» (H3_G)

Pertsona erreferente haiekin izandako harremanen eraginak, kasu honetan eragin onak, lanbide horretan aritzeko grina piztu zien. Hala, praxi hura errepikatzen dute gaur egun, ikasleekin nahiz seme-alabekin. Jardunbide hori bizi-filosofiatzat hartu dute, eta haien bizitzaren edozein arlotara hedatzen da (familia, lagunak, lankideak, ikasleak eta abar).

\section{Dilemak eta gatazkak irakaskuntza-jardunbidean}

Hezkuntzan, eta, beraz, irakaskuntzan, tentsio handiko egoerak izaten dira behar lukeenaren eta errealitatearen artean, justiziari, zuzentasunari eta demokraziari dagokienez.

Ikastetxe eta ikasgeletan egiten diren jarduerek, haiek egiteko moduek, sortzen diren harremanek eta haien eraginek arrastoa uzten dute ikasleengan zein bertan denbora luzez lan egiten duten hainbat gizon eta emakumerengan (Escudero, 2011).

«Tutore izan nintzen lehenengo urtean, ikasturte amaieran, ikasleei eskatu nien tutore gisa nola ikusi ninduten komentatzeko. Haietako batek eskerrak eman zizkidan: esan zidan bera entzun zuen pertsona baka- 
rra izan nintzela. Komentario hark aztarna utzi zuen nigan; alde batetik, poza sentitu nuen, ikaslearengana iritsi nintzelako; baina, bestetik, pentsatu nuen «ze bakarrik egon behar duen mutil honek niri hori esateko». Asko pentsarazi zidan, eta ikaslearengatik tristura sentitu nuen.» (H2_E)

Gure kolaboratzaileek, ikerlan honetan, gertakizun ugari identifikatzen dituzte gertakari kritikoak kategorian sartzen direnak. Haien arabera, gertakariok bizi izanari esker, teknika berriak planteatu eta garatu dituzte, gustuko izan zituzten edo ez zituzten bizipen haietan oinarriturik.

«Egia da irakasle gisa 24 urteko esperientzia luzea izanik, beti gazteekin, askotariko uneak bizi izaten direla, batzuetan atsegingarriak eta beste batzuetan ez hainbeste. Baina, arraroa dirudien arren, uste dut esan dezakedala momentu atsegingarri guztiak nire ikasleek sortu izan dituztela, eta INOIZ EZ dituztela haiek sortu momentu txarrak.» (H1_G)

Hirurak bat datoz: gertakari haiek kritikoak izan ziren - eta oraindik ere halaxe dira - haien bizitzetan. Batzuk onak eta beste batzuk, berriz, ez; baina kolaboratzaileetako inork ez ditu, inola ere, ikasleak gertakari desatseginen erantzule bakar gisa jotzen. Adierazten dute gehienetan saiatu izan direla, estrategien bitartez, erantzukizunaren pisua ez zedin soil-soilik ikasleen bizkar ezarri, hausnarketa-ariketak eginez, hartara ikasleak epaitzea saihesteko, kasurik gehienetan kaltegarria izan ohi baita haientzat.

«Izututa geratu nintzen, ikastetxeko korridore batetik igarotzean, ikusi nuenean nola irakasle batek apurtzen zion ikasle bati lan bat, ikaskide guztien aurrean. Horrekin nahikoa ez, eta, gainera, esan zion berarekiko (irakaskearekiko) errespetu falta zela...» (H1_G)

Era berean, irakasleek salatzen dituzte irakasleen eta ikasleen arteko botere-harremanetan oinarritutako jardunbide desegokiak; alegia, irakasle askoren agintekeria. Beren esanetan, irakasle horiek duten adina edozein dela ere, «Cuéntame telesailetik ateratakoak» dirudite (E2_ $\mathrm{F}^{1}$ kontakizun etnografikoa), ereduaren bitartez predikatu ez, eta, gainera, zernahi egiten baitute ikasleen gainetik jartzeko, aintzat hartu gabe zer subjektu eta eduki diren aurrean dituztenak.

A) «Irakaslea eskolan beti txiklea jaten. Ikusten du ikasle bat txiklea jaten, eta botatzeko agintzen dio. Baina, zer da hau?»

B) «Lankide bati orri batzuk erortzen zaizkio mahaitik, eta ikasle batek barre egiten du. Horren aurrean, irakasleak galdetzen dio ea zertaz ari

${ }^{1}$ Bigarren kolaboratzailea, emakumea. 
den barrez. Ikaslea ixildu egiten da. Horrekin nahikoa ez, eta agintzen dio altxatzeko eta paperak jasotzeko. Ikasleak uko egiten dio. Irakaslea aginduarekin tematzen da. Tentsio handia; gehiegi. Azkenean, ikasleak etsi egiten du eta paperak jasotzen ditu. Hori gutxi balitz bezala, irakasleak mehatxu egiten dio esanez azken aldia izan dadila, bestela arazo serio bat izango duela.» (H3_G)

Irakasle batzuek kasu gehienetan norgehiagoka-sentimenduak proiektatzen dituzte. Sentimendu horiek ikasleek haienganako agertzen duten desengainuaren ondorioz sortzen dira, eta irakasleok ez dute hori onartzen, hain zuzen, kasu askotan, apaltasun faltagatik edota ez dutelako beren jardunbideari buruzko gogoeta egiteko gaitasunik. Horren oinarrian, botere-harremanak daude; alegia, irakaslea ikasleen gainetik dagoela uste izatea.

Kolaboratzaileek salatzen dute irakasle askok kritikatzen dutela ikasleen jarrera kritiko eta jarduera eza, eta, ondoren, irakasle horiek berek erreklamazioren bat jasoz gero, desadostasuna agertzen dietela ikasleei, esanez erabilitako bitartekoak ez direla egokiak: adierazten diete irakasleak ebaluatzeko ebaluazio-prozesu bat badagoela, eta bertan agertu daitezkeela desadostasunak. Ebaluazio hori urtean behin izaten da, eta ikasturte amaieran.

«Egun batean, liskar gogor samarra izan nuen ikasle batekin. Ez naiz oroitzen zehazki zer esaldi bota nion, baina iruditu zitzaidan pasatu egin nintzela: "ganbara pitzatu zaizu, burua galdu duzu". Hurrengo egunean, ikasgelara iritsi, eta, lehenengo gauza, barkamena eskatu nion ikaskide guztien aurrean. Haren erantzuna izan zen "buah, lasai, ohituta nago etengabe halako erantzunak edo okerragoak jasotzen”.» (H2_E)

Agerian uzten dute zer tratu ematen zaien «txarrak» - modu desegokian - deritzen ikasleei, ez dituztelako betetzen gizarteak ezarritako baldintzak. Are gehiago, ikasleek berek ere justifikatzen dute jasotako tratu hori, esanez normala dela, irakasleentzat zaila baita haiekin lan egitea.

«Tutore izan naizenean tokatu izan zait lankideak defendatzea defentsa horretan sinetsi gabe, nire erosotasunagatik, lankideekin muturtuta ez ibiltzearren. Baina, zinez, esan behar nieke: "aizu, pasatu egin zara, askatu soka pixka bat, eta onartu; hitz egin mutilarekin”.» (H2_E)

Era berean, ikerlan honetan parte hartu duten irakasleek azaltzen dutenez, ez oso harro, noizbait izan duten jokaeraren bat, inola ere bat ez datozena, baina justifikatzen dutena. Agertzen dute nola batzuetan lankideren baten aldeko jarrera hartu behar izan duten, nahiz eta arrazoirik ez izan, rollo txarrak saihestearren. 
Zigorrak, eta haien adierazgarri nagusia, «gehigarri» ${ }^{2}$ deritzona, neurrigabe erabiltzea salatzen dute, egoera konplexuen aurrean gehien erabiltzen diren bitarteko pedagogiko gisa. Erabilera neurrigabe horrek liskarrak sortu izan ditu hainbat alditan irakasleen artean. Haren aldekoek arazoak «konpontzeko» bitartekoa dela justifikatzen dute; kontrakoek, aldiz, uste dute egoera zehatzetan bakarrik erabili beharreko bitartekoa dela.

\section{(In)Justizia soziala eta eskola}

Atal honetan, ikerlana eragin duen galderari erantzutearren, kolaboratzaileek bizi izandako egoera errealak aurkeztuko dira:

«Norbaitek giltzak ematen ez badizkit, esan nahi du ez duela konfiantzarik nigan... Guraso batzuek hiru urteko umea uzten dute ikastetxe batean. Zer handiagorik seme-alaba norbaitekin uztea, eta norbait hori izatea Alfredo, Imanol, Pepe, Juan edo Silviaren moduko bat? Ez ditugu ezagutzen; eta ezezagun batekin uzten dugu seme-alaba. Bada, horretan konfiantzarik ez baduzu, ba... Niri gurasoek seme-alabak uzten badizkidate, jakina, izango da nitaz fidatzen direlako, gauzak ondo egiten ditudala uste dutelako. Eta nik diot, gurasoek seme-alabak uzten badizkidate, nolatan ikastetxe batek ezin ditu giltza batzuk utzi?» (H1_G)

Kolaboratzaile batek hezkuntza arloko, eta, zehazkiago, bere ikastetxeko konfiantza faltari buruz hitz egiten du. Azaltzen du nola konfiantza falta horrek zuzenean eragiten duen irakasleen motibazioan, eta, beraz, haien jardunbide profesionalean. Irakasleen ondoeza horrek zurrunbilo arriskutsu bat elikatzen du, eta horretan murgiltzen dira haien praxi desegokia justifikatzeko.

«Inmigrazioaren gaian, a zer aurreiritziak dauden... Batzuetan, esaldi batzuk entzun, eta esaten duzu "nora zoaz?". Gustatuko litzaidake zu pertsona horien azalean ikustea, bizitza aurrera ateratzen saiatzeko beste herrialde batzuetara joan, eta halaxe trata zaitzatela. Batzuetan, mespretxuz hitz egiten da ikasleei buruz, hori da "Machupichu" edo "badakizu-eta hauek nondik datozen, eta beraz dira..." Ez dakit, jende askok orokortu egiten du. Beraz, nik uste dut etorkinak pertsona gisa tratatu beharrean, gehiago tratatzen direla kolektibo gisa, denak berdin, bakoitzak bere nortasuna izango ez balu bezala.» (H2_E)

Beste kolaboratzaile batek azaltzen du bere ikastetxeko irakasleentzat inmigrazioa gehiago dela arazo bat, kultura desberdinak ezagutzeko edota

2 Ohartarazteko gaztigu larria, ikasleak kaleratzea ekar dezakeena. 
lanerako aukera baino, eredu horrek (A eredua) duen eskaera handia dela medio. Baina irakasle gehienek zigor baten moduan bizi dute ikasle horiekin lan egin behar izatea. Halaber, komentatzen du askotan entzun eta ikusi behar izan duela etorkinak kolektibo gisa tratatzen, ezaugarri komunekin, kontuan hartu gabe norbanakoa eta bakoitzaren nortasuna.

«Murrizketak, murrizketak eta murrizketak hezkuntzan. Gero eta ikasle gehiago ditugu ikasgeletan, eta, ondorioz, ezin diegu eskaini ikastetxe elitistetara joaten diren ikasle dirudunei eskaintzen zaien kalitate bera. Ikastetxe horietan ikasle gutxiago dituzte, baliabide gehiago, errefortzuak... Ideala litzateke ikasgela bakoitzeko 10 ikasle izatea, eta 36 dituzunean, ba...» (H2_E)

Bukatzeko, beste kolaboratzaile batek nabarmentzen du bizi diren murrizketetan oinarritutako politika sozialek oso modu negatiboan eragiten diotela hezkuntzaren kalitateari. Adierazten du kontua ez dela arazoa sahiestea, baizik eta gaur egungo hezkuntza-errealitatearen argazkia egitea; izan ere, legeak ezartzen du DBHn ikasgela bakoitzean 30 ikasle izan behar direla gehienez, eta hori gainditu egiten da.

\section{EMAITZEI BURUZKO EZTABAIDA}

Ikus daitekeen moduan, kolaboratzaile guztiek aipatzen dute lagun egite emozionalaren alderdi positiboa, eta nola eragin dien horrek haien garapen pertsonal zein profesionalean. Bizitzan erreferente dituzten pertsona horiei buruz esaten dute ongizate emozionala errazten dutela, haien portaerak kolaboratzaileengan izan zuen eragin positiboak ekarri dien osasun mentalaren ondorioz. Halako eragina izan dute, ezen pertsona gisa nahiz hezkuntza arloan errepikatu nahi izan baitituzte haien portaerak (Pacheco eta Fernández-Berrocal, 2013).

Estimu handiz oroitzen dute pertsona horiek nola sentiarazi zituzten, entzun eta arreta eskaini zietenean. Azken finean, haiek maitatuak sentitu ziren. Horrek irakaskuntzako jardunbidean eragin die, arrakastaz bete dute curriculumak ezarritakoa, aldez aurretik ikasleekin «konplitu» baitute.

Hortaz, arreta eskaini behar zaie bizitzetako arlo guztietan sortzen diren emozioei, bereziki hezkuntzaren arloan, Campos et al.-ek $(1983 ; 1989)$ esan bezala, pertsonarentzat esanguratsuak eta garrantzitsuak diren edo izan diren gertakariekiko erreakzio-ereduak baitira.

Kolaboratzaileak oso kontzientziatuta daude beren irakaskuntza-jardunbidearekin, eta garrantzi handia ematen diete ikaskuntza-irakaskuntza prozesuan sortzen diren konpetentzia sozioemozionalei, zeinek, Repetto eta Peñak (2010) adierazi bezala, modu positiboan eragiten baitute gure ikasleen ikaskuntzan. 
Ikerlaneko gure kolaboratzaileen ustez, pertsonaren dimentsioen baitan, kontuan hartu beharreko beste alderdi bat da irakasleen prestakuntzak eta birziklapenak ikasleengan duten ondorioa. Nabarmentzen dute kontuan hartu behar dela prestakuntza jasotzeak duen garrantzia, nola kontzeptu eta prozeduretan, hala konpetentzia sozioemozionaletan, azken horrek ere garrantzi handia baitu hezkuntzaren arloan (Weissberg eta Greenberg, 1998).

Horrenbestez, esan daiteke, jardunbide profesionala arrakastatsua izan dadin, «amonaren errezeta» dela, hain zuzen, irakasleek konpetentzia emozionalen arloan jasotako prestakuntzan eta irakaskuntza-jardunbidean izandako dilema zein gatazketan oinarriturik garatutako jardunbidea.

Hezkuntzak aldaketa sozialerako motor gisa duen egitekoa eta erantzukizuna nabarmentzen dute irakasleek, Murillo eta Hernández-Castillak (2014) adierazitakoaren ildo berean. Alabaina, irakasleen artean dagoen ezinegona ere azpimarratzen dute. Ezinegon horren kausak dira gizarteak eta instituzioak haiengan duten konfiantza falta, desberdintasun sozialak, eta desberdintasun-egoera horiei aurre egiteko ezer ez edo gutxi egiten duten politikak. Izan ere, kolaboratzaileen arabera, gizarte justuagoak eraikitzen hasteko, horiek dira errotik erauzi beharreko aldagaiak.

Kolaboratzaileak ondorio batera heltzen dira: arazo horiek konpontzeko giltza, neurri handi batean, geure baitan dago, irakasleongan, eta ikastetxeetan eguneroko jardunean justizia sozialaren balioak ordezkatzen ditugunon identitateetan (Krichesky et al., 2011).

Baina ez dute nahi erantzukizun osoa irakasleona izatea. Horren haritik, zera diote: «katearen azken begia sendoa izango bada, kate osoak ere hala izan behar $d u »\left(\mathrm{E} 3 \mathrm{M}^{3}\right.$ kontakizun etnografikoa). Baieztapen horren bitartez, zenbait faktorek, hala nola unibertsitateak, agintariek eta gainerako hezkuntza-eragileek, justizia soziala bilatu zein garatzeko prozesuan duten funtzionaltasunari buruzko hausnarketa egiten dute kolaboratzaileek. Adierazten dute hezkuntzaren arloan modu positiboan eragingo lukeen elkarlana sustatu beharrean, nor bere burua gordetzen eta zaintzen dabilela, edo hala dirudiela behintzat.

Amaitzeko esan daiteke, gaur egungo gizartearen konplexutasuna dela eta, irakasleen rolak aldatzen aritzeaz gain, eskolaren eta irakasleen aukerak ere mugatzen ari direla justizia sozialaren printzipioetan oinarritutako kalitatezko hezkuntzaren aldeko borrokan aritzeko.

\section{ONDORIOAK ETA PROPOSAMENAK}

Ikasleei kalitatezko hezkuntza eskaintzea dagokigu irakasleoi. Hezkuntza honen bitartez testuingurua edozein delarik ere, haien parekideekin in-

3 Hirugarren irakaslea, gizonezkoa. 
plikatzeko prest egongo diren ikasleak sortuko lirateke. Hezkuntza honek gizarte justuago baten oinarriak finkatu ditzake, baina helburu hori betetzeko eskola kultura zehatz bat ezarri behar da. Instituzioetan aldaketak eragitea helburu duen hezkuntza eredu bat ezarri behar da; Justizia Sozialetik Justizia Sozialaren alde jardungo duen eredua.

Justizia Sozialean trebatzeko, ikastetxearen hezkuntza praktikek justiziaz jardun behar dute, eta ikasleak ardatz dituen eredua eraiki.

Berrikuntza prozesu honetan, funtsezkoa izango da irakasleen zeregina. Haiek sustatu eta ezarri beharko dute eredu berri hau. Alferrikako ahalegina litzateke helburu berritzaileak ezartzea, edukiak aldatzea, estrategiak eta metodologiak antolatzea, baldin eta esku-hartuko duen kolektiboa (irakasleena) aldaketa horiei ekiteko prest ez badago.

Irakasleek nekea pilatzen dute eguneroko jarduraren eta erronken ondorioz. Motibazio eza eragin dezake horrek, eta inplementaziorako traba bihurtu.

Lan honen helburua ez da irakaslegoaren jarrera justifikatzeko ahalegin bat, haien tentsioak eta dilemak sakonago ulertzeko ahalegin bat baizik. Irakasleek haien praktika profesionalean zehar aurre egin beharko diete tentsio horiei eta haiekin talkan eraikiko dute haien irakasle identitatea.

Amaitzeko, aipatu nahi genuke XXX eskolak gizarte justu bat sortzeko egokiak ez diren praktikak darabiltzala eta haietan sakontzen duela. Lan honek egoera arazotsu horietako batzuk identifikatu ditu. Horien aurrean, Hezkuntzatik eta Hezkuntzarako lan egiteko interesa duten pertsonak batuko dituzten guneak eta dinamikak sortzea da gure gomendioa. Gune horiek justizia sozialerako hausnarketa guneak izan beharko lukete eta konponbideei buruzko gogoeta egiteko espazio. Horrela soilik lortuko da justizia sozialaren kontzeptuari tratamendu naturalizatua ematea.

\begin{abstract}
Our contemporary society experiments constant change in a multiplicity of levels. This reality affects not only the school, but also the teachers themselves, changing their role and fundamental task as well as what we expect from them. This society is reckoned with the need to face fundamental challenges that affect its economic, social and cultural development, further exacerbating social injustices: Thus, this reality leads many governments to develop policies to preserve justice in our societies: In this context offering a quality education for social
\end{abstract}


justice becomes a fundamental issue. The main goal of this article is to contrast educational policies with school practices in order to better understand the role of teachers. Indeed, we are trying to answer the question that has undoubtedly been the main reason to carry out this research: Is the school an institution that reproduces and deepens the problems of social injustice? The methodology used has been a case study with a narrative approach. In conclusion, the complexity of contemporary society is not only transforming the teaching roles, but also limiting the possibilities of the school and its teachers to struggle for greater social justice.

Keywords: Educational practices, education and school, social justice, secondary education, narrative research.

El permanente cambio de la sociedad contemporánea, afecta no solo a la escuela, también a la tarea del propio profesorado, cambiando su rol y lo que esperamos de ellos. Esta sociedad, se ve en la necesidad de afrontar varios y numerosos retos que repercuten en su desarrollo económico, social y cultural exacerbando las injusticias sociales, llevando a numerosos gobiernos a desarrollar políticas para hacer de nuestra sociedad una sociedad más justa, donde la condición necesaria sea disponer de una educación de calidad que trabaje desde y para la justicia social. El objetivo fundamental es contrastar las políticas educativas con las prácticas escolares en aras de conocer y comprender el papel de los docentes, intentando responder a la pregunta que sin duda alguna ha sido la guía para llevar a cabo esta investigación: ¿Es la escuela una institución que reproduce y profundiza los problemas de la injusticia social? La metodología utilizada ha sido un estudio de caso con un enfoque narrativo. Como conclusión, la complejidad de la sociedad contemporánea está no solo transformando los roles docentes, sino también limitando las posibilidades de la escuela y su profesorado en la lucha por una mayor justicia social.

Palabras clave: Prácticas educativas, educación y escuela, justicia social, educación secundaria, investigación narrativa .

Le changement constant de la société contemporaine affecte non seulement l'école, mais également le travail du professorat, en modifiant son rôle et ce que nous attendons de lui. Cette société se retrouve dans le besoin d'affronter des défis divers et nombreux qui se répercutent sur son développement économique, social et culturel en exacerbant les injustices sociales et en poussant de nombreux gouvernements à mettre en place des politiques pour faire de notre société une société plus juste, où la condition nécessaire soit de disposer d'une éducation de qualité qui æuvre par et pour la justice sociale. L'objectif fondamental est de comparer les politiques éducatives aux pratiques 
scolaires afin de connaître et de comprendre le rôle des enseignants, en essayant de répondre à la question qui a sûrement déjà servi de base pour réaliser cette recherche : L'école est-elle une institution qui reproduit et amplifie les problèmes de l'injustice sociale ? La méthodologie utilisée a été une étude de cas avec une approche narrative. En résumé, la complexité de la société contemporaine non seulement transforme les rôles des enseignants, mais limite également les possibilités de l'école et de son professorat dans la lutte pour une plus grande justice sociale.

Mots-clé: pratiques éducatives, l'éducation scolaire, la justice sociale, l'enseignement secondaire, la recherche narrative.

\section{BIBLIOGRAFIA}

Abiétar, M.; Navas, A.; Marhuenda, F. (2015). Aportaciones desde la Justicia Social para una Educación Justa. La Identidad Pedagógica en Formación Profesional Básica. Revista Internacional de Educación para la Justicia Social, 4(2), 145-161.

Achili, E. (1996). Práctica docente y diversidad sociocultural. Rosario: Homo Sapiens:

Ainscow, M. (2001). Desarrollo de escuelas inclusivas: Ideas, propuestas y experiencias para mejorar las instituciones escolares. Madril: Narcea Ediciones.

Arribas, H. (2008). El pensamiento y la biografía del profesorado de actividad física en el medio natural: Un estudio multicaso en la formación universitaria orientado a la comprensión de modelos formativos. Doktorego-tesia. Universidad de Valladolid.

Bell, L.A. (1997). Teaching for diversity and social justice: a sourcebook. New York: Routledge.

Bisquerra, R. (2016). 10 ideas clave. Educación emocional (Vol. 26). Bartzelona. Grao.

Blanco, G. (2006). La equidad y la inclusión social: uno de los desafíos de la educación y la escuela hoy. REICE-Revista Electrónica Iberoamericana sobre Calidad, Eficacia y Cambio en Educación, 4(3).

Bourdieu, P. eta Passeron, J.C. (2014). La reproducción: elementos para una teoría del sistema de enseñanza. Mexiko: Fontamara.

Buendía Eisman, L.; Colás Bravo, M. P.; Hernández Pina, F. (1999). Métodos de investigación en psicopedagogía. Madril: McGraw-Hill.

Campos, J.J.; Barrett, K.C.; Lamb, M. E.; Goldsmith, H.H.; Stemberg, C. (1983). Socioemotional development. Handbook of Child Psychology and Developmental Science: 2 (4) 435-571.

Charmaz, K. (2008). Constructionism and the Grounded Theory Method. Handbook of Constructionist Research. New York, Guilford.

Cole, M. (2000). Education, equality and human rights: Issues of gender, 'race,' sexuality, special needs and social class. Londres: Routledge/Falmer Press. 
Dieterlen, P. (2001). Derechos, necesidades básicas y obligación institucional. Buenos Aires: Clacso.

Enterline, S.; Cochran-Smith, M.; Ludlow, L.; Mitescu, E. (2008). Learning to teach for social justice: Measuring changes in the beliefs if teacher candidates. The New Educator, 4, 267-290.

Escudero, J.M. (2011). Dilemas éticos de la profesión docente. Participación Educativa, 16, 93-102.

Fraser, N. (2008). Escalas de justicia. Bartzelona: Herder Editorial.

Fraser, N.; Honneth, A. (2003). Redistribution or recognition?: A Political-philosophical Exchange. Londres: Verso Press.

Gordon, S. (2001). Ciudadanía y derechos sociales: criterios distributivos?: «Pobreza, desigualdad social y ciudadanía. Los límites de las políticas sociales en América Latina», 23-37.

Holstein, J.A.; Gubrium, J.F.(2008) Handbook of constructionist research. New York: Guilford.

Imbernón Muñoz, F.; Martínez Bonafé, J. (2008). Innovar en la teoría y en la práctica. Cuadernos De Pedagogía, (385), 62-65.

Irvine, J.J. (2003). Educating teachers for diversity: Seeing with a cultural eye. New York: Teachers College Press.

Karsz, S. (2004). «La exclusión: concepto falso, problema verdadero». Bartzelona: Gedisa.

Krichesky, G.J.; Martínez, C.; Martínez, A.M.; García, A.; Castro, A.; González, A. (2011). Hacia un programa de educación docente para la justicia social. REICE-Revista Electrónica Iberoamericana sobre Calidad, Eficacia y Cambio en Educación. 9(4), 63-77.

Lakoff, G.; Johnson, M. (1980). Metaphors we live by . Chicago: Chicago University Press..

Lee, C.C.; Hipolito-Delgado, C. (2007). Counselors as agents of social justice. Counseling for Social Justice, 13-28. Alexandria,: American Counseling Association.

Mallimaci, F.; Giménez-Béliveau, V. (2010) Historias de vida y métodos biográficos. Estrategias de investigación cualitativa, 1(1), 23-60.

Miller, D. (1999). Principles of social justice. Cambridge, MA: Harvard University Press.

Monereo, C.; Pozo, J.I. (2011). La Identidad en psicología de la educación. Madril: Narcea Ediciones.

Mora, F. (2017). Neuroeducación. Madril: Alianza Editorial.

Murillo, F.J.; Hernández-Castilla, R. (2011). Educación para la Justicia Social. REICE-Revista Electrónica Iberoamericana sobre Calidad, Eficacia y Cambio en Educación, 9(4).

Murillo, J.F.; Román, M.; Hernández-Castilla, R. (2011). Evaluación Educativa para la JS. Revista Iberoamericana de Evaluación Educativa, 4(1).

Murillo, F.J.; Hernández-Castilla, R. (2014). Liderando escuelas justas para la justicia social. Revista Internacional de Educación para la Justicia Social (RIEJS).

Pacheco, N.N.E.; Fernández-Berrocal, P. (2013). Inteligencia emocional en adolescentes. Padres y Maestros, 352, 34-39. 
Polkinghorne, D.E. (2005). Language and meaning: data collection in qualitative research. Journal of Counseling Psychology, 52(2), 137-145.

Rawls, J.A. (1971). A theory of justice. Cambridge, MA: Harvard University Press.

Repetto, E.; Peña, M. (2010). Las competencias socioemocionales como factor de calidad en la educación. REICE-Revista Electrónica Iberoamericana sobre calidad, eficacia y cambio en educación.

Saldaña, J. (2013). The Coding Manual for Qualitative Researchers. Londres: Sage.

Sancho, J.M.; Correa, J.M.; Giró, X.; Fraga, L. (Koord.) (2014). Aprender a ser docente en un mundo en cambio. Nazioarteko sinposioa. Bartzelona: Dipòsit Digital de la Universitat de Barcelona.

Sen, A. (2010). La idea de la Justicia. Madril: Taurus.

Simons, H. (2009). El estudio de caso: Teoría y práctica. Madril: Morata.

Stake, R.E. (1995). The art of case study research. Thousand Oaks (CA). Sage Publications.

Unesco (2004). Temario abierto sobre educación inclusiva: materiales de apoyo para responsables de políticas educativas. Santiago: Oreal Unesco.

Unesco (2015). Informe de Seguimiento de la EPT en el mundo. La educación para todos 2000-2015: logros y desafíos. Ediciones UNESCO.

Wells, G. (2001). Indagación Dialógica. Hacia una teoría y práctica socioculturales de la educación. Espainia: Paidós. 